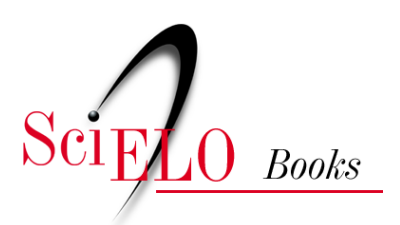

\title{
11 Tribo Cardueae Cass.
}

\author{
Angelo Alberto Schneider
}

SCHNEIDER, A.A. Tribo Cardueae Cass. In: ROQUE, N. TELES, A.M., and NAKAJIMA, J.N., comp. A família Asteraceae no Brasil: classificação e diversidade [online]. Salvador: EDUFBA, 2017, pp. 85-87. ISBN: 978-85-232-1999-4. https://doi.org/10.7476/9788523219994.0013.

All the contents of this work, except where otherwise noted, is licensed under a Creative Commons Attribution 4.0 International license.

Todo o conteúdo deste trabalho, exceto quando houver ressalva, é publicado sob a licença Creative Commons Atribição $\underline{4.0}$.

Todo el contenido de esta obra, excepto donde se indique lo contrario, está bajo licencia de la licencia Creative Commons Reconocimento 4.0 . 


\section{TRIBO CARDUEAE CASS.}

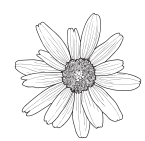

Angelo Alberto Schneider

A tribo Cardueae é uma das maiores da família, com cerca de 2.400 espécies, distribuídas em 72 gêneros (SUSANNA; GARCIA-JACAS, 2007, 2009), e está representada principalmente por espécies conhecidas popularmente como "cardos", devido à presença de espinhos e projeções espinescentes por toda a planta. Apresenta distribuição euroasiática (principalmente mediterrânea), com poucos representantes na África e América.

\section{Descrição}

Ervas anuais, bianuais ou perenes, geralmente com projeções espinescentes por toda a planta; células laticíferas geralmente presentes nas partes aéreas. Raízes com ductos de resina. Folhas alternas, frequentemente dispostas em roseta, inteiras, mais comuns lobadas e decorrentes, espinescentes ou não. Capitulescência corimbiforme, raro glomeriforme, ou solitários em escapo. Capítulos discoides ou disciformes, raro radiados, homógamos ou heterógamos, com muitas flores; brácteas involucrais imbricadas em várias séries, espinescentes ou não, foliáceas ou membranáceas, com ápice fimbriado, lacerado, inerme ou espinescente; receptáculo escamoso ou setoso, raramente glabro. Flores normalmente com corola tubulosa, férteis ou estéreis na periferia, corola geralmente actinomorfa, raro zigomorfa; estames com anteras sagitadas, caudadas na base, apêndice do conectivo rígido, lignificado e lanceolado, filetes glabros ou papilosos; estilete com um espessamento papiloso-piloso logo abaixo da divisão dos 
ramos do estilete, estilopódio presente. Cipselas variáveis, estreitas ou espessas, lustrosas, raro rostradas, glabras ou hirsutas, inserção do carpopódio basal, basal-lateral ou lateral; pápus escamoso ou cerdoso, geralmente duplo, raramente ausente.

A tribo Cardueae está representada no Brasil por 7 gêneros: Arctium L. (Figura 6B), Carduus L. (Figura 6C), Carthamus L. (Figura 6D), Centaurea L. (Figuras 6E-F), Cirsium Mill. (Figura 6G), Cynara L. e Silybum Vaill., sendo que, destes, apenas Centaurea apresenta uma única espécie autóctone, $C$. tweediei Hook. \& Arn. (Figura 6F), que ocorre no estado do Rio Grande do Sul.

\section{Chave de identificação para os gêneros de Cardueae no Brasil}

1. Cipselas com carpopódio inserido basalmente 2

1'. Cipselas com carpopódio inserido lateralmente 6

2. Plantas inermes; brácteas involucrais subuladas, ápice em forma de gancho (Figura 6B). Arctium

2'. Plantas com espinhos; brácteas involucrais espinescentes, ápice reto (sem forma de gancho) (Figuras 6E-F). 3

3. Lâmina foliar branco-variegada; brácteas involucrais com espinhos laterais; pápus de cerdas decíduas. Silybum 3'. Lâmina foliar coloração uniforme (não branco-variegada); brácteas involucrais sem espinhos laterais; pápus destacado em anel.

4. Cerdas do pápus simples Carduus

4'. Cerdas do pápus plumosas 5

5. Plantas cultivadas; receptáculo carnoso; cipsela com carúncula globosa no ápice. Cynara 5'. Plantas subespontâneas; receptáculo não carnoso; cipsela sem carúncula no ápice Cirsum 
6. Capítulos com brácteas involucrais foliáceas (Figura 6D); cipselas dimórficas (mais externas sem pápus, rugosas, e mais internas com pápus, lisas

Carthamus

6'. Capítulos com brácteas involucrais escariosas, raramente foliáceas (Figuras 6E-F); cipselas isomórficas Centaurea

\section{Literatura recomendada}

CABRERA, A. L. Compositae. In: BURKART, A. (Org.). Flora Ilustrada de Entre Rios (Argentina). Buenos Aires: Colecion Cientifica del INTA. 1974. p. 106-554.

SUSANNA, A.; GARCIAS-JACAS, N. Tribe Cardueae. In: KADEREIT, J. W.; JEFFREY, C. (Ed.). The Families and Genera of Vascular Plants: v. 8: Flowering Plants: Eudicots - Asterales. Berlin: Springer-Verlag, 2007. p. 123-147.

SUSANNA, A.; GARCIAS-JACAS, N. Cardueae. In: FUNK, V. A.et al. (Ed.) Systematics, Evolution and Biogeography of Compositae. Viena: IAPT, 2009. p. 249-265. 